\title{
Respon pertumbuhan true shallot seed beberapa varietas bawang merah (Allium cepa l.) terhadap aplikasi giberelin
}

\author{
(Response of true shallot seed growth in some onion varieties (Allium cepa L.) to giberelin \\ application)
}

\author{
I. S. Elshyana, D. R. Lukiwati dan Karno \\ Agroecotechnology, Faculty of Animal and Agricultural Sciences, \\ Diponegoro University \\ Tembalang Campus, Semarang 50275 - Indonesia \\ Corresponding E-mail:elshyana@gmail.com
}

\begin{abstract}
This research aimed to determine the growth response of several shallot seed varieties to several doses of $\mathrm{GA}_{3}$ to the growth of shallots. This research was conducted on March 5 - July 62018 at Screen House Agroecotechnopark and Laboratory of Physiology and Plant Breeding, Diponegoro University, Semarang. This research will use Factorial Completely Randomized Design $4 \times 3$ with 4 replications. The first factor is the dosage of $\mathrm{GA}_{3}$ to consist of 4 levels: $\mathrm{M} 0=0 \mathrm{ppm}, \mathrm{M} 1=50 \mathrm{pm}, \mathrm{M} 2=100 \mathrm{ppm}$ and $\mathrm{M} 3=$ $200 \mathrm{ppm}$. The second factor is that some varieties of shallot seeds consist of 3 levels: V1= Bima, V2= Tutuk and V3= Lokananta. The parameters observed were vigor index, germination, maximum growth potential, plant height, number of leaves, number of tillers and total wet weight of plants. Data were analyzed for variance and tested further with Duncan's Multiple Range Test (DMRT). The results showed that the treatment of $100 \mathrm{ppm} \mathrm{GA3}$ with Lokananta varieties gave significantly higher results than other treatments, in the vigor index parameters and sprout power. The treatment of $50 \mathrm{ppm}$ GA3 dosage with tuktuk varieties gave significantly higher results than other treatments, in the number of leaves and shallots.
\end{abstract}

Keywords: Allium cepa L., true shallot seed, gibberellin, growth.

\begin{abstract}
ABSTRAK
Penelitian ini bertujuan untuk mengetahui respon pertumbuhan beberapa varietas benih bawang merah terhadap beberapa dosis $\mathrm{GA}_{3}$ terhadap pertumbuhan bawang merah. Penelitian ini dilaksanakan pada tanggal 5 Maret - 6 Juli 2018 di Screen House Agroecotechnopark dan Laboratorium Fisiologi dan Pemuliaan Tanaman, Universitas Diponegoro, Semarang. Penelitian ini akan menggunakan Rancangan Acak Lengkap Faktorial $4 \times 3$ dengan 4 kali ulangan. Faktor pertama yaitu dosis $\mathrm{GA}_{3}$ terhadap terdiri atas 4 taraf yaitu M0: 0 ppm, M1: 50 pm, M2:100 ppm dan M3: 200 ppm. Faktor kedua yaitu beberapa varietas benih bawang merah terdiri atas 3 taraf yaitu V1: Bima, V2: Tutuk dan V3: Lokananta. Parameter yang diamati yaitu Indek vigor, daya kecambah, potensi tumbuh maksimum, tinggi tanaman, jumlah daun, jumlah anakan dan berat basah total tanaman. Data dianalisis ragam dan diuji lanjut dengan Duncan's Multiple Range Test (DMRT). Hasil penelitian menunjukkan perlakuan dosis $\mathrm{GA}_{3} 100 \mathrm{ppm}$ dengan varietas Lokananta memberikan hasil nyata lebih tinggi dibanding perlakuan lainnya, pada parameter indeks vigor dan daya kecambah. Perlakuan dosis $\mathrm{GA}_{3} 50 \mathrm{ppm}$ dengan varietas tuktuk memberikan hasil nyata lebih tinggi dibanding perlakuan lainnya, pada jumlah daun dan anakan bawang merah.

Kata Kunci : Allium cepa L., true shallot seed, giberelin, pertumbuhan.
\end{abstract}




\section{PENDAHULUAN}

Bawang merah merupakan salah satu komoditas hortikultura unggulan yang telah lama digunakan oleh petani sebagai usaha yang memiliki nilai ekonomi tinggi dan banyak digunakan untuk kebutuhan sehari-hari sebagai bahan campuran industri makanan, bahan konsumsi rumah tangga dan obat-obatan (Pandiangan et al., 2015). Kebutuhan bawang merah meningkat setiap tahunnya untuk konsumsi (industri, rumah tangga, dan benih) namun belum diikuti dengan bertambahnya jumlah produksi. Hal tersebut disebabkan oleh pemilihan bibit yang kurang tepat, sulitnya mendapatkan bibit yang bebas hama dan penyakit, dan penggunaan varietas tanaman yang tidak sesuai dengan lingkungan setempat (Rosliani et al., 2014).

Salah satu upaya untuk mendapatkan bibit yang memiliki mutu tinggi yaitu dengan cara memperbaiki mutu genetik benih (Badrudin et al. 2007). Hal tersebut dapat dilakukan dengan pemilihan varietas benih yang sesuai dengan lingkungan setempat dan memiliki potensi tinggi sehingga mempengaruhi daya hasil dan adaptasi varietas tersebut (Haq dan Iskandar, 2014).

Bawang merah dapat diperbanyak secara vegetatif dan generative, masing-masing menggunakan umbi dan benih. Penggunaan umbi sebagai bahan tanam secara terus menerus dapat menurunkan kualitas hasil umbi, karena dapat menurunkan hasil produksi. Penyakit yang disebabkan oleh Colletotrichum sp., Fusarium sp., dan Altenaria sp., serta virus sering terbawa oleh umbi yang berasal dari induk tanaman (Sumarni at al. 2012). Perkembangan teknologi terkini budidaya bawang merah dapat dilakukan menggunakan benih (True Shallot Seed).

Penanaman dengan benih belum begitu dikembangkan dikalangan petani. Hal tersebut disebabkan karena terdapat kendala dalam pembudidayaan bawang dengan benih salah satunya yaitu daya tumbuh rendah (Widiarti et al., 2017). Penanaman benih bawang untuk dapat tumbuh dan berproduksi tinggi, membutuhkan bahan tambahan berupa zat pengatur tumbuh (ZPT). Zat pengatur tumbuh merupakan suatu bahan yang mekanisme berperan dalam metabolisme tanaman. Salah satu zat pengatur tumbuh yang dapat meningkatkan daya berkecambah benih bawang merah yaitu hormon Giberellic Acid $\left(\mathrm{GA}_{3}\right)$ (Sumarni, 2010). Menurut Maria at al. (2013) giberelin berperan dalam pertumbuhan dan pembelahan sel, pemecah dormansi benih dan memobilisasi endosperm selama pertumbuhan awal embrio

Menurut Haq dan Iskandar (2014) perlakuan aplikasi $\mathrm{GA}_{3} 100 \mathrm{ppm}$ dengan perendaman selama 30 menit pada varietas manjung dapat meningkatkan tinggi tanaman dan jumlah daun pada bawang merah. Sorensen at al. (2015) menyatakan bahwa perlakuan pemberian dosis $\mathrm{GA}_{3} 20$, 40, dan 60 ppm dengan lama perendaman 30, 60, dan 90 menit tidak berpengaruh terhadap pertumbuhan prtumbuhan bawang merah serta belum dapat mendorong proses pembentukan biji pada tanaman bawang merah. Barson et al. (2015) menyatakan bahwa perlakuan perendaman $\mathrm{GA}_{3}$ 200 ppm selama 90 menit dapat meningkatkan jumlah tanaman berbunga dan bobot biji tertinggi pada proses produksi biji bawang merah. Menurut Wulandari et al. (2014) aplikasi giberelin selama 4

Tabel 1. Indeks Vigor True Shallot Seed Beberapa Benih Bawang Merah pada Dosis Giberelin yang berbeda

\begin{tabular}{cccccc}
\hline \hline \multirow{2}{*}{ Varietas } & \multicolumn{4}{c}{ Dosis $\mathrm{GA}_{3}(\mathrm{ppm})$} & \multirow{2}{*}{ Rerata } \\
\cline { 2 - 5 } & 0 & 50 & 100 & 200 & \\
\hline & & $-------(\%)------$ & & \\
Bima & $3,13 \pm 0,63^{\mathrm{f}}$ & $6,25 \pm 0,72^{\mathrm{f}}$ & $6,88 \pm 1,20^{\mathrm{f}}$ & $8,13 \pm 1,20^{\mathrm{f}}$ & $6,09 \pm 1,06^{\mathrm{c}}$ \\
Tuktuk & $36,88 \pm 2,13^{\mathrm{e}}$ & $47,50 \pm 6,69^{\mathrm{de}}$ & $46,25 \pm 5,99^{\mathrm{de}}$ & $51,88 \pm 5,53^{\mathrm{cd}}$ & $45,62 \pm 3,16^{\mathrm{b}}$ \\
Lokananta & $61,88 \pm 4,13^{\mathrm{c}}$ & $74,38 \pm 3,13^{\mathrm{b}}$ & $92,50 \pm 1,44^{\mathrm{a}}$ & $86,25 \pm 2,60^{\mathrm{a}}$ & $78,75 \pm 6,77^{\mathrm{a}}$ \\
\hline Rerata & $33,95 \pm 17,02^{\mathrm{b}}$ & $42,71 \pm 19,81^{\mathrm{a}}$ & $48,54 \pm 24,74^{\mathrm{a}}$ & $48,75 \pm 22,61^{\mathrm{a}}$ & \\
\hline
\end{tabular}

Keterangan : Superskrip pada baris rerata, kolom rerata dan matrik interaksi menunjukkan perbedaan nyata $(\mathrm{P}<0,05), \operatorname{tanda} \pm$ menunjukkan standard error 
jam dengan umur semai 2 minggu dapat meningkatkan presentase perkecambahan sebesar $85,33 \%$ pada varietas tuktuk.

Penelitian ini bertujuan untuk mengkaji respon pertumbuhan true shallot seed beberapa varietas bawang merah terhadap beberapa dosis $\mathrm{GA}_{3}$ serta mengetahui interaksi antara beberapa varietas bawang merah dan beberapa dosis $\mathrm{GA}_{3}$ terhadap pertumbuhan true shallot seed bawang merah.

\section{MATERI DAN METODE}

Penelitian telah dilaksanakan pada tanggal 5 Maret - 6 Juli 2018 di Screen House Agroecotechnopark dan Laboratorium Fisiologi dan Pemuliaan Tanaman, Departemen Pertanian, Fakultas Peternakan dan Pertanian, Universitas Diponegoro, Semarang.

\section{Materi}

Bahan yang digunakan dalam penelitian yaitu benih bawang merah varietas Bima, Tuktuk dan Lokananta dari Balai Penelitian Tanaman Sayur dan PT. West Seed, aquades, etanol 96\%, tanah, pupuk kompos, sekam, Gibberelic Acid (GA), pupuk NPK 16-16-16. Alat yang digunakan dalam penelitian yaitu gelas ukur, pipet, gelas plastik, timbangan analitik, tray, dan polybag.

\section{Metode}

Tahap persiapan penelitian meliputi persiapan media tanam dengan komposisi tanah, sekam, dan pupuk perbandingan (1:1:1). Media yang telah tercampur dimasukkan ke dalam tray dan polybag. Persiapan bahan meliputi pemilihan varietas benih yaitu Lokananta, Tuktuk dan Bima. Tahap perlakuan dengan pembuatan larutan $\mathrm{GA}_{3}$ dengan dosis $0,50,100$, dan $200 \mathrm{ppm}$. Benih yang telah disiapkan direndam selama 4 jam.

Persiapan pembibitan dilakukan dengan mempersiapkan tray yang telah diisi dengan media tanam, kemudian benih ditanam dilakukan penyiraman setiap harinya. Bibit yang telah berumur 21 hari dipindah tanam dalam polybag dengan setiap polybag terdiri atas 2 tanaman.

Perawatan dilakuan dengan penyiraman pada pukul 06.00 dan 16.30 WIB pada saat proses pembibitan, namun setelah berumur 45 hari penyiraman dilakukan sehari sekali setiap pagi atau sore hari. Pemupukan dilakukan pada hari ke35 dan ke- 60 setelah tanam dengan pupuk NPK 16-16-16. Dosis yang digunakan yaitu $0,35 \mathrm{gram} /$ polybag. Pengendalian hama penyakit dilakukan jika diperlukan. Tahap pemanenan dilakukan pada umur 90 hari dengan ciri tanaman yaitu daun mengering atau menguning $20-80 \%$, pangkal daun mulai rempes, daun pada tanaman rebah $75 \%$, dan umbi muncul ditas permukaan tanah berwarna merah keunguan.

\section{Rancangan Percobaan dan Analisis Data}

Penelitian ini menggunakan Rancangan Acak Lengkap (RAL) Pola Faktorial 4x3 dengan 4 kali ulangan. Faktor pertama yaitu dosis $\mathrm{GA}_{3}$ terdiri atas 4 taraf yaitu M0: 0 ppm, M1: $50 \mathrm{pm}, \mathrm{M} 2: 100$ ppm dan M3: 200 ppm. Faktor kedua yaitu beberapa jenis varietas biji bawang merah terdiri atas 3 taraf yaitu V1: Bima, V2: Tutuk dan V3: Lokananta. Data yang diperoleh kemudian dianalisis ragam dan dilanjutkan dengan uji jarak berganda Duncan (Duncan's Multiple Range Test

Tabel 2. Daya Kecambah True Shallot Seed Beberapa Benih Bawang Merah pada Dosis Giberelin yang berbeda.

\begin{tabular}{cccccc}
\hline \hline \multirow{2}{*}{ Varietas } & \multicolumn{4}{c}{ Dosis $\mathrm{GA}_{3}(\mathrm{ppm})$} & \multirow{2}{*}{ Rerata } \\
\cline { 2 - 5 } & 0 & 50 & 100 & 200 & \\
\hline & & $--------(\%)-------$ & & \\
Bima & $6,25 \pm 0,88^{\mathrm{f}}$ & $10,31 \pm 1,07^{\mathrm{f}}$ & $10,63 \pm 1,49^{\mathrm{f}}$ & $11,88 \pm 1,30^{\mathrm{f}}$ & $9,76 \pm 1,22^{\mathrm{c}}$ \\
Tuktuk & $41,25 \pm 1,53^{\mathrm{e}}$ & $50,63 \pm 7,24^{\mathrm{de}}$ & $47,19 \pm 5,96^{\mathrm{de}}$ & $55,94 \pm 4,37^{\mathrm{d}}$ & $48,74 \pm 3,08^{\mathrm{b}}$ \\
Lokananta & $68,75 \pm 3,10^{\mathrm{c}}$ & $82,19 \pm 1,64^{\mathrm{b}}$ & $93,75 \pm 1,14^{\mathrm{a}}$ & $90,31 \pm 1.18^{\mathrm{ab}}$ & $83,74 \pm 5,56^{\mathrm{a}}$ \\
\hline Rerata & $38,75 \pm 18,09^{\mathrm{b}}$ & $47,70 \pm 20,08^{\mathrm{a}}$ & $50,5 \pm 24,06^{\mathrm{a}}$ & $52,70 \pm 22,70^{\mathrm{a}}$ & \\
\hline
\end{tabular}

Keterangan : Superskrip pada baris rerata, kolom rerata dan matrik interaksi menunjukkan perbedaan nyata $(\mathrm{P}<0,05), \operatorname{tanda} \pm$ menunjukkan standard error 
$=D M R T)$ pada taraf $5 \%(\mathrm{P}<0,05)$.

\section{HASIL DAN PEMBAHASAN}

\section{Indeks Vigor Benih Bawang Merah}

Hasil analisis ragam menunjukkan bahwa perlakuan yang diberikan berpengaruh nyata terhadap parameter indeks vigor benih bawang merah. Terdapat interaksi nyata antara meningkatkan level giberelin yang terdapat dalam benih sehingga dapat memicu proses perkecambahan. Barson et al. (2015) menyatakan bahwa penambahan hormon $\mathrm{GA}_{3}$ dapat memacu perkecambahan yang berperan dalam memecah senyawa amilum menjadi glukosa pada endosperma sebagai sumber energi sehingga cadangan makanan tersedia untuk proses perkecambahan. Semakin lama benih direndam

Tabel 3. Potensi Tumbuh Maksimum True Shallot Seed Beberapa Benih Bawang Merah pada Dosis Giberelin yang berbeda

\begin{tabular}{lcc}
\hline \hline & Perlakuan & Potensi Tumbuh Maksimum \\
\hline Bima & Varietas Bawang & $----\%----$ \\
Tuktuk & & $14,06 \pm 1,64^{\mathrm{c}}$ \\
Lokananta & & $42,81 \pm 11,4^{\mathrm{b}}$ \\
& \multirow{2}{*}{ Dosis $\mathbf{G A}_{3}$} & $88,75 \pm 4,51^{\mathrm{a}}$ \\
$0 \mathrm{ppm}$ & & \\
$50 \mathrm{ppm}$ & & $31,45 \pm 22,08^{\mathrm{b}}$ \\
$100 \mathrm{ppm}$ & & $52,71 \pm 21,84^{\mathrm{a}}$ \\
$200 \mathrm{ppm}$ & & $53,33 \pm 22,70^{\mathrm{a}}$ \\
\hline
\end{tabular}

Keterangan : Superskrip berbeda pada tiap kolom perlakuan menunjukkan perbedaan nyata $(\mathrm{P}<0,05)$, tanda \pm menunjukkan standard error

perendaman beberapa dosis $\mathrm{GA}_{3}$ dan beberapa varietas bawang merah. Hasil uji Duncan indeks vigor benih bawang merah tercantum pada Tabel 1.

Hasil uji Duncan menunjukkan bahwa perlakuan beberapa dosis $\mathrm{GA}_{3}$ pada varietas lokananta menunjukkan perbedaan nyata terhadap indeks vigor benih bawang merah. Pemberian dosis $100 \mathrm{ppm}$ pada varietas lokananta berbeda tidak nyata dengan dosis $200 \mathrm{ppm}$, namun berbeda nyata dengan 50 dan 0 ppm terhadap indeks vigor benih bawang merah. Pemberian dosis $0 \mathrm{ppm}$ pada varietas tuktuk tidak berbeda nyata dengan dosis 50 dan $100 \mathrm{ppm}$, namun berbeda nyata dengan dosis $200 \mathrm{ppm}$ terhadap indeks vigor bawang merah. Pemberian beberapa dosis $\mathrm{GA}_{3}$ pada varietas bima berbeda tidak nyata terhadap indeks vigor bawang merah. Perlakuan perendaman dosis $100 \mathrm{ppm}$ pada varietas lokananta yaitu $92,50 \%$ nyata lebih tinggi $(\mathrm{P}<0,05)$ dibanding dengan perlakuan yang lainnya. Pemberian $\mathrm{GA}_{3}$ dapat meningkatkan vigor benih bawang merah dan maka semakin lama proses imbibisi dalam benih sehingga semakin banyak air dan giberelin yang terdapat dalam benih. Asra (2014) menyatakan bahwa proses imbibisi dalam benih akan meningkatkan laju respirasi yang akan mengaktifkan enzim yang terdapat dalamnya. Aktivitas metabolisme, giberelin yang dihasilkan dalam embrio ditranslokasikan ke aleuron menjadi enzim alfa amilase. Alfa amilase masuk ke dalam cadangan makanan mengubah pati menjadi gula sebagai energi untuk aktivitas sel dan pertumbuhan.

\section{Daya Kecambah Benih Bawang Merah}

Hasil analisis ragam menunjukkan bahwa perlakuan yang diberikan berpengaruh nyata terhadap parameter daya kecambah benih bawang merah. Terdapat interaksi nyata antara perendaman beberapa dosis $\mathrm{GA}_{3}$ dan beberapa varietas bawang merah. Hasil uji Duncan daya kecambah benih bawang merah tercantum pada Tabel 2. 
Tabel 4. Tinggi Tanaman True Shallot Seed Beberapa Benih Bawang Merah pada Dosis Giberelin yang berbeda

\begin{tabular}{lcc}
\hline \hline & \multirow{2}{*}{ Perlakuan } & Tinggi Tanaman \\
\hline \multirow{2}{*}{ Bima } & Varietas Bawang & $----c m-----$ \\
Tuktuk & & $45,75 \pm 0,33^{\mathrm{b}}$ \\
Lokananta & & $54,81 \pm 0,14^{\mathrm{a}}$ \\
& & $59,73 \pm 0,14^{\mathrm{ab}}$ \\
$0 \mathrm{ppm}$ & Dosis GA3 & \\
$50 \mathrm{ppm}$ & & $51,82 \pm 3,06$ \\
$100 \mathrm{ppm}$ & & $51,16 \pm 3,06$ \\
$200 \mathrm{ppm}$ & & $50,57 \pm 2,17$ \\
\hline
\end{tabular}

Keterangan : Superskrip berbeda pada tiap kolom perlakuan menunjukkan perbedaan nyata $(\mathrm{P}<0,05)$, tanda \pm menunjukkan standard error

Hasil uji Duncan menunjukkan bahwa perlakuan beberapa dosis $\mathrm{GA}_{3}$ pada varietas lokananta menunjukkan perbedaan nyata terhadap daya kecambah benih bawang merah. Pemberian dosis $100 \mathrm{ppm}$ pada varietas lokananta berbeda nyata dengan dosis 50 dan $0 \mathrm{ppm}$, namun berbeda tidak nyata dengan $200 \mathrm{ppm}$ terhadap daya kecambah benih bawang merah. Pemberian dosis $0 \mathrm{ppm}$ pada varietas tuktuk berbeda tidak nyata dengan dosis 50 dan $100 \mathrm{ppm}$, namun berbeda nyata dengan dosis $200 \mathrm{ppm}$ terhadap daya kecambah benih bawang merah. Pemberian beberapa dosis $\mathrm{GA}_{3}$ pada varietas bima tidak berpengaruh nyata terhadap indeks vigor bawang merah. Perlakuan perendaman dosis $100 \mathrm{ppm}$ pada varietas lokananta yaitu $93,75 \%$ nyata lebih tinggi $(\mathrm{P}<0,05)$ dibanding dengan perlakuan yang lainnya. Hal tersebut dikarenakan biji terimbibisi secara optimum, sehingga giberelin dapat bereaksi dalam metabolisme pada benih dan berpengaruh terhadap pembelahan dan pertumbuhan sel pada tanaman. Supardy et al. (2016) menyatakan bahwa proses awal perkecambahan benih yaitu benih membutuhkan air untuk proses penyerapan agar dapat terimbibisi dengan baik. Air yang telah diserap oleh biji mengakibatkan kulit pada biji lunak dan terjadi hidrasi protoplasma, kemudian enzim menjadi aktif terutama pada enzim yang dapat mengubah lemak menjadi energi melalui proses respirasi. Maryani dan Irfandi (2008) menyatakan bahwa giberelin berperan dalam memobilisasi cadangan makanan dengan menghasilkan energi dan unsur hara, selanjutnnya diikuti dengan pembentukan senyawa protein. Hasil dari energi akan membentuk sel-sel baru dengan diikuti proses difersiasi sel yang akan membentuk plumula dan radikula.

\section{Potensi Tumbuh Maksimum Bawang Merah}

Hasil analisis ragam menunjukkan bahwa perlakuan yang diberikan berpengaruh nyata terhadap parameter potensi tumbuh maksimum benih bawang merah. Tidak terdapat interaksi nyata antara perendaman beberapa dosis $\mathrm{GA}_{3}$ dan beberapa varietas bawang merah Hasil uji Duncan potensi tumbuh maksimum benih bawang merah tercantum pada Tabel 3 .

Hasil uji Duncan menunjukkan bahwa perlakuan varietas berpengaruh nyata terhadap potensi tumbuh maksimum benih bawang merah. Perlakuan varietas lokananta memberikan hasil potensi tumbuh maksimum $88,75 \%$ nyata lebih tinggi $(\mathrm{P}<0,05)$ dibanding dengan varietas tuktuk dan bima. Hal tersebut dikarenakan perbedaan daya potensi tumbuh benih dikarenakan oleh varietas yang memiliki sifat genetik yang berbeda pada benih bawang merah. Sorensen et al. (2015) menyatakan bahwa setiap varietas memiliki sifat genetik yang berbeda. Masing-masing varietas untuk dapat tumbuh dengan keberhasilan yang tinggi memerlukan lingkungan yang optimal. Wulandari et al. (2014) menyatakan bahwa 
Tabel 5. Jumlah Daun True Shallot Seed Beberapa Benih Bawang Merah pada Dosis Giberelin yang berbeda.

\begin{tabular}{|c|c|c|c|c|c|}
\hline \multirow{2}{*}{ Varietas } & \multicolumn{4}{|c|}{ Dosis $\mathrm{GA}_{3}(\mathrm{ppm})$} & \multirow{2}{*}{ Rerata } \\
\hline & 0 & 50 & 100 & 200 & \\
\hline \multicolumn{6}{|c|}{---------(helai)---------- } \\
\hline Bima & $1,38 \pm 0,09^{\mathrm{f}}$ & $1,31 \pm 0,03^{\mathrm{f}}$ & $1,46 \pm 0,14^{\text {de }}$ & $1,37 \pm 0,03^{\mathrm{f}}$ & $1,38 \pm 0,03^{\mathrm{b}}$ \\
\hline Tuktuk & $1,56 \pm 0,03^{\mathrm{bc}}$ & $1,68 \pm 0,03^{\mathrm{a}}$ & $1,42 \pm 0,03^{\mathrm{ef}}$ & $1,51 \pm 0,03^{\mathrm{bc}}$ & $1,54 \pm 0,05^{\mathrm{a}}$ \\
\hline Lokananta & $1,62 \pm 0,05^{\mathrm{ab}}$ & $1,49 \pm 0,04^{\text {cd }}$ & $1,56 \pm 0,07^{\mathrm{bc}}$ & $1,55 \pm 0,03^{\mathrm{bc}}$ & $1,56 \pm 0,03^{\mathrm{a}}$ \\
\hline Rerata & $1,52 \pm 0,07$ & $1,49 \pm 0,11$ & $1,48 \pm 0,04$ & $1,48 \pm 0,06$ & \\
\hline
\end{tabular}

Keterangan : Superskrip pada kolom rerata dan matrik interaksi menunjukkan perbedaan nyata $(\mathrm{P}<0,05)$, tanda \pm menunjukkan standard error

varietas bima memiliki kulit biji lebih tebal sehingga biji sulit untuk menyerap air, dan memiliki cadangan makan yang belum cukup tersedia untuk pertumbuhan emrio, sehingga daya kecambah rendah. Tuktuk dapat berkecambah dengan normal, namun tidak memiliki kekuatan tumbuh terhadap keadan yang tidak normal.

Hasil uji Duncan menunjukkan bahwa perlakuan perendaman beberapa dosis $\mathrm{GA}_{3}$ memberikan hasil potensi tumbuh maksimum benih nyata lebih tinggi $(\mathrm{P}<0,05)$ dibanding tanpa perlakuan $\mathrm{GA}_{3}$. Perendaman 200 ppm menunjukkan pertumbuhan tertinggi yaitu $56,66 \%$. Pemberian dosis $200 \mathrm{ppm}$ dapat meningkatkan cadangan makanan untuk proses perkecambahan dalam benih sehingga benih dapat tumbuh secara optimal. Asra (2014) menyatakan bahwa perendaman benih dengan dosis 200 ppm dapat meningkatkan vigoritas dan daya kecambah karena pemberian dosis secara optimal dapat meningkatkan proses perkecambahan pada tanaman. Supardy et al.
(2016) menyatakan bahwa perlakuan perendaman dengan $\mathrm{GA}_{3}$ merupakan teknik imbibisi secara terkontrol. Proses perendaman mengakibatkan keserempakan dalam proses perkecambahan dan mengurangi akan tekanan terhadap lingkungan.

\section{Tinggi Tanaman}

Hasil analisis ragam menunjukkan bahwa perlakuan yang diberikan berpengaruh nyata terhadap parameter tinggi tanaman benih bawang merah. Tidak terdapat interaksi nyata antara perendaman beberapa dosis $\mathrm{GA}_{3}$ dan beberapa varietas bawang merah. Hasil uji Duncan tinggi tanaman tercantum pada Tabel 4.

Hasil uji Duncan menunjukkan bahwa perlakuan varietas tuktuk tidak berbeda nyata dengan varietas lokananta, namun berbeda nyata dengan varietas bima. Perlakuan varietas lokananta nyata lebih tinggi $(\mathrm{P}<0,05)$ dibanding dengan varietas bima dan tuktuk. Perbedaan

Tabel 6. Jumlah Anakan True Shallot Seed Beberapa Benih Bawang Merah pada Dosis Giberelin yang berbeda

\begin{tabular}{|c|c|c|c|c|c|}
\hline \multirow{2}{*}{ Varietas } & \multicolumn{4}{|c|}{ Dosis $\mathrm{GA}_{3}(\mathrm{ppm})$} & \multirow{2}{*}{ Rerata } \\
\hline & 0 & 50 & 100 & 200 & \\
\hline \multicolumn{6}{|c|}{---------(helai)---------- } \\
\hline Bima & $1,00 \pm 0,00^{c}$ & $1,55 \pm 0,18^{a b}$ & $1,55 \pm 0,18^{\mathrm{ab}}$ & $1,37 \pm 0,21^{\mathrm{b}}$ & $1,35 \pm 0,13$ \\
\hline Tuktuk & $1,00 \pm 0,00^{c}$ & $1,73 \pm 0,00^{\mathrm{a}}$ & $1,00 \pm 0,00^{c}$ & $1,00 \pm 0,00^{\mathrm{c}}$ & $1,18 \pm 0,18$ \\
\hline Lokananta & $1,00 \pm 0,00^{c}$ & $1,00 \pm 0,00^{\mathrm{c}}$ & $1,62 \pm 0,21^{\mathrm{a}}$ & $1,55 \pm 0,18^{\mathrm{ab}}$ & $1,29 \pm 0,17$ \\
\hline Rerata & $1,00 \pm 0,00^{\mathrm{b}}$ & $1,42 \pm 0,22^{\mathrm{a}}$ & $1,38 \pm 0,19^{\mathrm{a}}$ & $1,28 \pm 0,16^{\mathrm{a}}$ & \\
\hline
\end{tabular}

Keterangan : Superskrip pada baris rerata dan matrik interaksi menunjukkan perbedaan nyata $(\mathrm{P}<0,05)$, tanda \pm menunjukkan standard error 
varietas ini disebabkan karena penggunaan varietas yang cenderung dipengaruhi oleh faktor genetik dan daya tumbuh benih. Sorensen et al. (2015) menyatakan bahwa adanya perbedaan tinggi tanaman antar varietas, maka dapat dijadikan penciri dari suatu varietas. Setiap benih memiliki kemampuan untuk tumbuh dalam memaksimalkan penggunaan unsur hara, cahaya dan hormon giberelin. Haq dan Iskandar (2014) menyataan bahwa tinggi tanaman merupakan salah satu indikator pertumbuhan. tinggi tanaman tidak ada korelasinya dengan hasil atau produksi tanaman.

Hasil uji Duncan menunjukkan bahwa tinggi tanaman pada beberapa level dosis perendaman tidak menunjukkan adanya perbedaan nyata. Hal tersebut disebabkan karena pemberian $\mathrm{GA}_{3}$ yang kurang optimal sehingga tidak berpengaruh terhadap tinggi tanaman bawang merah.
Hasil analisis ragam menunjukkan bahwa perlakuan yang diberikan berpengaruh nyata terhadap parameter jumlah daun benih bawang merah. Terdapat interaksi nyata antara perendaman beberapa dosis $\mathrm{GA}_{3}$ dan beberapa varietas bawang merah. Hasil uji Duncan jumlah daun tercantum pada Table 5 .

Hasil uji Duncan menunjukkan bahwa pemberian dosis $100 \mathrm{ppm}$ pada varietas bima memberikan hasil jumlah daun nyata lebih tinggi dibanding pemberian dosis 0,50 dan $200 \mathrm{ppm}$. Pemberian dosis $50 \mathrm{ppm}$ pada varietas tuktuk berbeda nyata dengan dosis 0,100 , dan $200 \mathrm{ppm}$, namun pemberian dosis $200 \mathrm{ppm}$ berbeda tidak nyata dengan dosis $0 \mathrm{ppm}$ terhadap jumlah daun bawang merah. Pemberian dosis 0,100 , dan 200 ppm pada varietas lokananta tidak menunjukkan perbedaan yang nyata, namun pemberian dosis 50 ppm menunjukkan perbedaan nyata terhadap

Tabel 7. Berat Basah Total True Shallot Seed Beberapa Benih Bawang Merah pada Dosis Giberelin yang berbeda

\begin{tabular}{lcc}
\hline \hline & Perlakuan & Berat Basah Total \\
-----gram----
\end{tabular}
standard error

Sitanggang et al. (2015) menyatakan bahwa pemberian ZPT pada tanaman hanya untuk pendorong dalam proses fisologis tanaman. Jika proses fisiologi pada tanaman telah berjalan maka zat pengatur tumbuh tidak akan lagi memberikan pengaruh yang nyata. Panca et al. (2014) menyatakan bahwa pemberiaan dosis $\mathrm{GA}_{3}$ yang telah mencapai titik optimum dan mencukupi kebutuhan tanaman, apabila dosis ditingkatkan lagi tidak akan berpengaruh terhadap tanaman.

\section{Jumlah Daun}

jumlah daun bawang merah. Perlakuan perendaman $50 \mathrm{ppm}$ varietas tuktuk memberikan hasil nyata lebih tinggi $(\mathrm{P}>0,05)$ dibanding dengan perlakuan yang lainnya. $\mathrm{GA}_{3}$ yang diberikan pada saat perendaman benih berpengaruh signifikan terhadap jumlah daun pada bawnag merah. $\mathrm{GA}_{3}$ berfungsi dalam proses pembelahan sel sehingga dapat menambahkan jumlah daun. Dosis $50 \mathrm{ppm}$ merupakan dosis optimum dalam pertumbuhan jumlah daun, jika pemberian dosis dinaikan lagi maka pertumbuhan akan terganggu. Haq dan Isqandar (2014) menyatakan bahwa pemebrian zat 
pengatur tumbuh pada tanaman bertujuan untuk mengontrol pertumbuhan agar diperoleh hasil yang maksimal. ZPT yang diberikan dalam konsentrasi rendah pada tanaman agar dapat mendorong pertumbuhan tanaman. Maria et al. (2013) menyatakan bahwa giberelin dalam memacu pertumbuhan jumlah daun pada tanaman yaitu pembelahan sel pada ujung tajuk, pembelahan sel dan peningkatan plastisitas dinding sel.

\section{Jumlah Anakan}

Hasil analisis ragam menunjukkan bahwa perlakuan yang diberikan berpengaruh nyata terhadap parameter jumlah anakan benih bawang merah. Terdapat interaksi nyata antara Perendaman beberapa dosis $\mathrm{GA}_{3}$ dan beberapa varietas bawang merah. Hasil uji Duncan jumlah anakan bawang merah tercantum pada Tabel 6 .

Hasil uji Duncan menunjukkan bahwa pemberian dosis $0 \mathrm{ppm}$ pada varietas lokananta tidak berbeda nyata dengan dosis $50 \mathrm{ppm}$, namun berbeda nyata dengan dosis 50 dan 100 ppm pada jumlah anakan bawang merah. Pemberian dosis 0 ppm pada varietas tuktuk tidak berbeda nyata dengan dosis 100 dan 200 ppm, namun berbeda nyata dengan dosis $50 \mathrm{ppm}$ pada jumlah anakan bawang merah. Pemberian dosis $0 \mathrm{ppm}$ pada varietas bima berbeda nyata dengan dosis 50, 100 dan $200 \mathrm{ppm}$, namun pemberian dosis $50 \mathrm{ppm}$ tidak berbeda nyata dengan dosis 100 dan 200 ppm pada jumlah anakan bawang merah. Perlakuan perendaman $50 \mathrm{ppm}$ varietas tuktuk nyata lebih tinggi $(\mathrm{P}<0,05)$ dibanding dengan perlakuan lainnya. Hal tersebut dapat diketahui bahwa respon dosis membantu terhadap jumlah umbi dan anakan. Pemberian dosis $50 \mathrm{ppm}$ merupakan dosis optimum pada varietas tuktuk, jika dosis dinaikan maka respon $\mathrm{GA}_{3}$ tidak nyata. Jumlah anakan yang terbentuk yaitu 1-2 anakan per tanaman. Sutrapraja (2007) menyatakan bahwa tanaman yang berasal dari biji rata-rata hanya membentuk 1 sampai 2 tanaman, karena tanaman langsung membentuk batang dan setiap biji hanya membentuk satu batang. Deden dan Trisnaningsih (2018) menyatakan bahwa dosis 50 ppm dapat meningkatkan jumlah umbi dan produksi pada tanaman.

\section{Berat Basah Total}

Hasil analisis ragam menunjukkan bahwa perlakuan yang diberikan berpengaruh nyata terhadap parameter berat basah total bawang merah. Tidak terdapat interaksi nyata antara perendaman beberapa dosis $\mathrm{GA}_{3}$ dan beberapa varietas bawang merah. Hasil uji Duncan berat basah total tercantum pada Table 7.

Hasil uji Duncan menunjukkan bahwa pemberian perlakuan varietas tuktuk tidak berbeda nyata dengan varietas lokananta, namun berbeda nyata dengan varietas bima pada berat basah total tanaman bawang merah. Varietas tuktuk nyata lebih tinggi $(\mathrm{P}<0,05)$ dibanding perlakuan yang lainnya, hal tersebut disebabkan oleh faktor genetik dan lingkungan tumbuh pada tanaman. Jasmi (2013) menyatakan bahwa varietas menetukan tinggi rendahya suatu produksi pada tanaman dan di dukung oleh faktor lingkungan. Varietas bima merupakan tanaman yang dapat tumbuh di dataran tinggi hingga dataran rendah, namun jika dibudidayakan di dataran rendah memiliki hasil yang rendah. Ciri tanaman yang memiliki berat atau produksi tinggi menurut Deden dan Trisnaningsih (2018) menyatakn bahwa tanaman bawang merah yang pertumbuhannya baik dapat dicirikan dengan daun yang lebih tinggi dan menghasilkan umbi yang lebih besar. Makanan yang dihasilkan saat pertumbuhan vegetatif disimpan dalam umbi, sehingga tingginya hasil panen disebabkan oleh karbohidrat yang dapat disimpan dalam umbi.

Hasil uji Duncan menunjukkan bahwa pemberian beberapa dosis $\mathrm{GA}_{3}$ pada bawang merah berpengaruh tidak nyata terhadap berat basah total. Hal tersebut disebabkan karena pemberian dosis $\mathrm{GA}_{3}$ kurang optimal sehingga tidak terjadi aktivitas metabolisme pada tanaman. Hal tersebut menyebabkan proses fotosintesis pada tanaman terhambat sehingga hasil fotosintesis tidak sampai pada umbi tanaman bawang. Deninta, dkk., (2017) menyatakan bahwa pemberian dosis $\mathrm{GA}_{3}$ yang sesuai dapat meningkatkan proses biokimia pada tanaman sehingga dapat meningkatkan proses fotosintesis dan hasil dari fotosintesis dapat digunakan untuk proses generatif hingga tanaman padat dipanen. Haq dan Iskandar (2014) menyatakan bahwa berat basah yang terdapat pada tanaman menunjukkan aktivitas metabolisme pada tanaman dan dipengaruhi oleh kandungan air pada tanaman, penyerapan unsur hara dan hasil dari 
metabolisme pada tanaman.

\section{KESIMPULAN}

Berdasarkan penelitian yang telah dilakukan dapat disimpulkan bahwa perlakuan pada dosis perendaman $\mathrm{GA}_{3} 100 \mathrm{ppm}$ dengan varietas lokananta dapat meningkatkan pertumbuhan perkecambahan pada bawang merah meliputi indeks vigor dan daya kecambah, sedangkan dosis $50 \mathrm{ppm}$ dengan varietas tuktuk dapat meningkatkan jumlah daun dan anakan bawang merah.

\section{DAFTAR PUSTAKA}

Asra, R. 2014. Pengaruh hormon giberelin terhadap daya kecambah dan vigoritas Calopogonium caeruleum. J. Biospecies. 7(1) 29-33

Badrudin, U., Sunarto dan P. Hidayat. 2007. Pertumbuhan produksi enam genotype bawang merah yang diperlakukan dengan variasi pupuk K dan saat panen. J. Agrin. 11(2) : 120-129.

Barson, Mariati dan Rosita. 2015. Produksi biji bawang merah samosir aksesi simanindo terhadap konsentrasi $\mathrm{GA}_{3}$ dan lama perendaman di dataran tinggi samosir. $J$. Agrotech 3 (3) : 1147-1146.

Deden dan U. Trisnaningsih. 2018. Pengaruh giberelin dan urin terhadap pertumbuhan dan hasil tanaman bawang merah. J. Agrosintesa 1(1): 18-29

Deninta, N., T. M. Onggo dan Kusumiyati. 2017. Pengaruh berbagai konsentrasi dan aplikasi metode hormon $\mathrm{GA}_{3}$ terhadap pertumbuhan dan hasil tanaman brokoli kultivar lucky. $J$. Agrikultur. 28(1): 9 -14.

Haq, M. M. N., dan I. Iskandar. 2014. Respon beberapa varietas bawang merah dan lamanya perendaman $\mathrm{GA}_{3}$ terhadap pertumbuhan dan hasil. J Agritop : 41- 50

Jasmi, E. Sulistyaningsih dan D. Indradewa. 2013. Pengaruh varietas umbi terhadap pertumbuhan, hasil dan perkembangan bawang merah di dataran rendah. J. I. Pert. $16(1): 42-57$.

Maria T., B. Maysiak and M. Krawic. 2013. The effect of storage temperature of stacking bulbs on seed stalk development and seed yield of shallot. Acta 66 (3): 41-48

Maryani, A. T., dan Irfandi. 2008. Pengaruh skarifikasi dan pemberian giberellin terhadap perkecambahan benih aren. J. Sagu 7 (1): 116.

Panca, P. S., A. Rasyad, dan Nurbaiti. 2016. Respon beberapa varietas kedelai terhadap pemberian giberelin. J. Faperta 1 (2)

Pandiangan, E., Mariati dan J. Ginting. 2015. Respon pertumbuhan hasil biji bawang merah terhadap aplikasi $\mathrm{GA}_{3}$ dan fosfor. $J$. Agrotek 3 (3): 1153-1158.

Rosliani, R., Y. Hilman, I. M. Hidayat, dan I. Sulistriani. 2014. Teknik produksi umbi mini bawang merah asal biji dengan jenis media tanam dan dosis NPK yang tepat di dataran rendah. Jurnal Horti. 24 (23) : 239-248.

Sitanggang, A., Islan, dan S. I. Saputra. 2015. Pengaruh pemberian pupuk kandang ayam dan zat pengatur tumbuh giberelin terhadap pertumbuhan bibit kopi arabika. J. Faperta 2 (1)

Sorensen, A., Mariati dan A.M. Siregar. 2015. Tanggap pertumbuhan vegetatif dan generatif bawang merah terhadap konsentrasi dan lama perendaman $\mathrm{GA}_{3}$ di dataran rendah. $J$. Agroekotek 3 (1) : 310-219

Sumarni, N., E. Sumiati dan Suwandi. 2010. Pengaruh kerapatan tanaman dan aplikasi zat pengatur tumbuh terhadap produksi umbi bibit bawang merah asal biji kultivar bima. $J$. Horti 15 (3): 208-214.

Sumarni, N., R. Rosliani, dan Suwandi. 2012. Optimalisasi jarak tanam dan dosis pupuk NPK untuk produksi bawang merah dari 
benih umbi mini dari dataran tinggi. J. Horti 22 (2): 148-155

Supardy, E. Adelina, dan U. Made. 2016. Pengaruh lama perendaman dan konsntrasi giberelin $\left(\mathrm{GA}_{3}\right)$ terhadap viabilitas benih kakao. J. Agrotekbis 2 (3) : 425-430

Sutapraja, H. 2007. Pengaruh naungan plastik transparan, kerapan tanaman dan dosis $\mathrm{N}$ terhadap produksi dan biaya produksi umbi mini asal biji bawang merah. Balai Penelitian

\section{Tanman Sayur}

Widiarti, W., I. Wijaya, dan Umarie. 2017. Optimalisasi teknologi produksi true shallot seed bawang merah. J. Agritrop 15 (2) : 203216

Wulandari, A., D. Purnomo, dan Supriyono. 2014. Potensi biji botani bawang merah (True Shallot Seed) sebagai bahan tanaman budidaya bawang merah di Indonesia 2(1) : 28-36. 